\title{
Comparative Anatomical Survey on the species of Iberis L. (Brassicaceae) from Turkey
}

\section{Türkiye'deki Iberis L. (Brassicaceae) Türlerinin Karşılaştırmalı Anatomisi}

\author{
Emre Çilden $^{1}{ }^{\oplus}$, Golshan Zare ${ }^{2}$ \\ ${ }^{1}$ Department of Biology, Faculty of Science, Hacettepe, University, Ankara, Turkey. \\ ${ }^{2}$ Department of Pharmaceutical Botany, Faculty of Pharmacy, Hacettepe University, Ankara, Turkey.
}

\section{ABSTRACT}

beris taxa natively found in Turkey are represented by eight species and are annual and/or perennial herbs or subshrubs. In this study, we provide a detailed anatomical description of Turkish Iberis taxa for the first time and try to solve the complexity of taxonomical uncertainties of the genus. Root, stem and leaf anatomies are investigated and stomatal index of Iberis is indicated. Our results provided valuable evidence on the doubtful circumstance of species in this genus. I. attica is the only species that has winged stem structure and branched trichomes. I. carica, one of the endemics, is the only species with its continuous vascular cambium in stem that forms a vascular bundle circle. I. sempervirens is the only species without indumentum which has also a subshrub habit. I. odorata is the only annual species. There are two types of leaf anatomy as bilateral and isolateral. Turkish Iberis taxa show amphistomatic leaves. Myrosin cells that are the characteristic of the order Brassicales are observed in all examined species. Anatomical results support that I. attica and I. spruneri are two separate taxa instead of as combined $I$. carnosa.

\section{Key Words}

Iberis, Brassicaceae, anatomy, Turkey.

\footnotetext{
T ürkiye'de doğal olarak yetişen Iberis cinsi ülkemizde 8 türle temsil edilmekte olup tek ve/veya çok yıllık otlar veya yarı çalılardan oluşmaktadır. Bu çalışmada, Türkiye'de yetişen Iberis taksonları anatomik olarak detaylı biçimde ilk defa çalışılmış ve bu sayede cinsle ilgili taksonomik belirsizlikler ve karmaşıklıklar çözülmeye çalışılmıştır. Iberis türlerinin kök, gövde, yaprak anatomileri çalışımış ve stoma indeksi ortaya konmuştur. Bu çalışmada elde edilen sonuçlar, cinsin türleriyle ilgili şüpheli durumların çözümü için değerli kanıtlar sağlamaktadır. I. attica kanatı gövde yapısına ve dallanmış tüylere sahip tek türdür. Endemik bir tür olan I. carica, gövde anatomisindeki devamlı vasküler kambiyum sayesinde iletim demeti halkası içeren tek türdür. I. sempervirens tüysüz ve yarı çalı formundaki tek türdür. I. odorata tek yıllıktır. Bilateral ve izolateral olmak üzere iki tip yaprak anatomisi görülmektedir. Türkiye'deki Iberis türleri amfistomatiktir. Brassicales ordosunun tipik özelliklerinden biri olan mirozin hücreleri incelenen tüm türlerde gözlenmiştir. Anatomik sonuçlar, I. attica ve I. spruneri türlerinin, I. carnosa olarak tek bir takson değil, ayrı türler olarak ele alınmasını desteklemektedir.
}

\section{Anahtar Kelimeler}

Iberis, Brassicaceae, anatomi, Türkiye.

Article History: Received: Feb 7, 2019; Revised: Jun 15, 2019; Accepted: Sep 7, 2019; Available Online: Nov 1, 2019

DOI: https://doi.org/10.15671/hibc.585877

Correspondence to: E. Çilden, Department of Biology, Faculty of Science, Hacettepe, University, Ankara, Turkey.

E-Mail: emrecilden@yahoo.com 


\section{INTRODUCTION}

r he genus Iberis L. (Brassicaceae) consists of about 28 species of annuals, perennials, and evergreen subshrubs worldwide [1,2]. Iberis is one of two genera of the tribe Iberideae Webb \& Berthel. besides Teesdalia W.T.Aiton which is diagnosed by monosymmetric flower structure in Brassicaceae family, as in Calepina Adans. [3]. Therefore, zygomorphic symmetry is seen in Iberis, instead of bilateral symmetry. Flower colours are white, red, pinkish or purplish. Corymbose infructescense, angustiseptate and two-seeded fruits are important diagnostic characters for identification of Iberis species [4]. It is currently represented by eight species in Turkey: $I$. carica (Bornm.) Prain, I. carnosa Willd., I. halophila Vural \& H. Duman, I. odorata L., I. saxatilis L., I. sempervirens L., I. simplex DC. and I. umbellata L. [5-14].

Secretory cells containing myrosin as one of the diagnostic characters of the order Brassicales are widely distributed through the family Brassicaceae, but their frequency is partially controlled by nutritional and environmental factors. In this family member, the stomata are surrounded by three subsidiary cells of which one of them is usually much smaller than the other two, the so-called cruciferous type. Hairs are unicellular, but maybe simple, unbranched, Y-shaped, two-armed, peltate, or dendroid; rarely glandular [15].

A formal classification has been proposed by Dahlgren [16], bringing most of these families together in a single order, based on their shared production of glucosinolates, precursors of the mustard oils that give Brussel sprouts and capers their characteristic taste. Mustard oils (or isothiocyanates) are hydrolytic products of glucosinolates and had been shown to occur in some families on the order Brassicales, including Brassicaceae, Resedaceae, Capparaceae, etc. by the early 1990s [17]. The conversion of glucosinolates to mustard oils is provided by the enzyme myrosinase, which is normally found in myrosin cells. Isothiocyanates, thiocyanates or nitryles, generated by hydrolises of glucosinolates function in defense mechanism of plant [17-19]. In addition, highly glycosylated flavonols in the non-flowering leafy shoots of $I$. saxatilis [20], antioxidant potential of $I$. sempervirens [21], and acylated pelargonidin glycosides occurrence in the red-purple flowers of I. umbellata [22] are reported. Plant defense mechanisms also include the production of secondary compounds that act as feeding deterrents or as toxins [23]. Also, it is stated that
I. amara (known as "bitter candytuft") is used as a remedy in homeopathy for some diseases such as asthma, bronchitis, dropsy, heart affections and is useful in the treatment of hypertrophy of the heart [24].

Although some studies have been carried out about the family Brassicaceae, the genus Iberis or some species of the genus [13, 14, 25-28], there are many points remain unresolved or doubtfully resulted.

In this study, we compile the limited information about anatomical properties of the Iberis species from literature and complement it with our new data. In addition, the aims of this study are to describe the anatomy of eight Iberis species from Turkey and evaluate the implementation and importance of anatomic structure on taxonomy of the genus.

\section{MATERIALS and METHODS}

Plant specimens used for this study were collected from different regions of Turkey. The data of all collected and examined plant specimens are listed in Table 1. Flora of Turkey and the East Aegean Islands [5] is used for identification of the species. I. umbellata, a cultivar species which is reported only from İstanbul, Turkey [12] has not been collected and evaluated.

The specimens are deposited in Hacettepe University Herbarium (HUB). Plant specimens were kept in $70 \%$ ethanol for anatomical investigations. Freehand sections were prepared using razor blades. In the anatomical analysis, paradermal sections and cross-sections were taken from the middle part of the leaves. Cross-sections of root were taken $1 \mathrm{~cm}$ above the base of the root and stem cross-sections from the lower part of the individuals. All sections are stained by double stain, containing astra blue and safranin in 9:1 ratio. Slides were observed with an Olympus CX41 microscope light microscope and photographed by DS-L1, DS-5M connected to Nikon Eclipse E600 camera. Data of all anatomical characters are based on the measurements of 30 sections of each taxon. Cluster analysis is carried out to determine the phenetic similarity between species. 18 qualitative and quantitative anatomical values are examined and listed in Table 2.

PAST (PAleontological STatistics) ver. 3.25 programme is used for the analysis [29]. Jaccard similarity index has been used to explain binary and multiple charac- 
Table 1. Locality information of collected and/or examined taxa (*: endemic taxa).

\begin{tabular}{|c|c|c|}
\hline Taxa & Voucher number & Locality \\
\hline 1. attica & E. Çilden 1807 & $\begin{array}{l}\text { İçel, between Gözne and Arslanköy, Yavca village, } 100 \mathrm{~m} \text {. } \\
\text { after the exit of village, road side, calcerous soil, } 36^{\circ} 1^{\prime} 6,74^{\prime \prime} \\
\text { N, } 34^{\circ} 31^{\prime} 59,27 \mathrm{E} \text {, ca. } 1200 \mathrm{~m}, 20.04 .2018 \text { (HUB). }\end{array}$ \\
\hline 1. attica & E. Çilden 1849 & $\begin{array}{c}\text { İzmir, Nif mountain, } 38^{\circ} 23^{\prime} 9,59^{\prime \prime} \mathrm{N}, 27^{\circ} 21^{\prime} 57,47 \mathrm{E}, 1290 \mathrm{~m} \text {, } \\
\text { calcerous soil, } 03.05 .2018 \text { (HUB). }\end{array}$ \\
\hline 1. attica & E. Çilden $1889 b$ & $\begin{array}{c}\text { Antalya, Alanya to Hadim village, } 36^{\circ} 34^{\prime} 30^{\prime \prime} \mathrm{N}, 32^{\circ} 22^{\prime} 4^{\prime \prime} \mathrm{E}, \\
1330 \mathrm{~m}, 21.10 .2018 \text {, leg. Ahmet Tiraş (HUB). }\end{array}$ \\
\hline 1. attica & E. Çilden 1841 & $\begin{array}{c}\text { Muğla, Köyceğiz, Hamitköy village, road side, } 36^{\circ} 54^{\prime} 43,29^{\prime \prime} \\
\text { N, } 28^{\circ} 37^{\prime} 12,8 \text { E, } 80 \text { m, 02.05.2018 (HUB). }\end{array}$ \\
\hline 1. attica & E. Çilden 1759 & $\begin{array}{c}\text { Muğla, between Marmaris-Datça, near Hisarönü village, } \\
\text { road side, } 36^{\circ} 47^{\prime} 29,05^{\prime \prime} \text { N, } 28^{\circ} 3^{\prime} 18,97^{\prime \prime} \text { E, } 33 \text { m, 17.03.2018 } \\
\text { (HUB). }\end{array}$ \\
\hline I. carica* & E. Çilden 1829 & $\begin{array}{l}\text { Aydın, Söke, Güllübahçe village, ruins of Priene anthic } \\
\text { city, in the screes, } 37^{\circ} 39^{\prime} 39,16^{\prime \prime} N, 27^{\circ} 17^{\prime} 52,1^{\prime \prime} E, 160 \text { m, } \\
02.05 .2018 \text { (HUB) (type locality). }\end{array}$ \\
\hline I. halophila* & E. Çilden 1766 & $\begin{array}{c}\text { Karaman, Eskil, near Tuz Gölü, salty soil, } 38^{\circ} 26^{\prime} 33,762^{\prime \prime} \mathrm{N}, \\
33^{\circ} 26^{\prime} 52,60 \mathrm{E}, 930 \mathrm{~m}, 31.03 .2018 \text { (HUB). }\end{array}$ \\
\hline 1. odorata & $\begin{array}{l}\text { H. Altınözlü 5877; A. Güner } \\
\qquad 8446\end{array}$ & $\begin{array}{c}\text { Mardin, Dargeçit, between Temelli and Kartalkaya villages, } \\
\text { 37,753578 E 37,4161454 N, } 739 \text { m, steppe, 12.04.2008 } \\
\text { (HUB); Hatay, Belen, calcerous fields, } 700 \text { m., 06.04.1991 } \\
\text { (HUB). }\end{array}$ \\
\hline I. saxatilis ssp. saxatilis & T. Dirmenci 2516a & $\begin{array}{c}\text { Balıkesir, Kazdağ (Ida), Nanekırı, limestone, } 1500 \text { m., } \\
\text { 19.05.2004 (HUB). }\end{array}$ \\
\hline I. saxatilis ssp. magnesiana* & D. Oskay 1376; E. Çilden 1895 & $\begin{array}{l}\text { Manisa, Soma district, Kocasivri hill, } 850 \text { m, May } 2011 \\
\text { (isotype); ibid 23.04.2019 (HUB). }\end{array}$ \\
\hline I. sempervirens & $\begin{array}{l}\text { E. Çilden 1891; B. Özüdoğru } \\
4001\end{array}$ & $\begin{array}{c}\text { Muğla, Ula, Sandras mountain, in the screes, } 37^{\circ} 2^{\prime} 11^{\prime \prime} \\
\text { N, } 28^{\circ} 48^{\prime} 3^{\prime \prime} \text { E, } 1960 \text { m, } 21.10 .2018 \text {, leg. Buse Topçuoğlu } \\
\text { (HUB); Kahramanmaraş, between Göksun-Geben, } \\
\text { Meryemçilbeli, 37,82231 N, 36,40699 E, ca. } 1800 \text { m, } \\
\text { 30.04.2016 (HUB). }\end{array}$ \\
\hline 1. simplex & $\begin{array}{l}\text { E. Çilden 1782; E. Çilden } \\
\qquad 1887\end{array}$ & 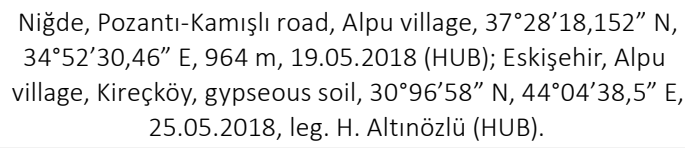 \\
\hline I. spruneri & $\begin{array}{l}\text { H. Yıldırım 3794; E. Çilden } \\
1334\end{array}$ & $\begin{array}{c}\text { Denizli, Çameli district, Karabayır, marly soil, } 36^{\circ} 55^{\prime} 59,5^{\prime \prime} \\
\text { N, } 29^{\circ} 8^{\prime} 55,3^{\prime \prime} \text { E, } 1610 \text { m, } 30.04 .2016 \text { (HUB); Aydın, above } \\
\text { Dağeymiri village, beyond Karlık tepesi, stony hills, } 1515 \text { m, } \\
24.04 .2010 \text { (HUB). }\end{array}$ \\
\hline
\end{tabular}

ters. Cluster analysis has been carried out by SAHN (Sequential Agglomerative Hierarchical Nested Cluster Analysis) and UPGMA (Unweighted Pair Group Method with Arithmetic Average) method. Anatomical measurements are made using an ocular micrometer on stereoscopic binocular Leica Zoom 2000, with a standard ruler; and results are listed in Table 3-5.

\section{RESULTS}

The anatomy of the specimens is determined by examination of root, stem and leaf sections, trichome and stoma structures (Figures 1-5); and additionally, stoma- tal index of the species is presented. In this study, I. attica Jordan and. I. spruneri Jordan are treated as two separate species instead of $I$. carnosa.

\section{Root anatomy}

Annual and perennial root anatomy is present. Only I. odorata has an annual habit, whereas all other Iberis taxa are perennial. Periderm is generally scratched from cortex. Cortex is multi-layered (ca. 6 to 20 layer) and includes sclereids in I. sempervirens, I. saxatilis, I. halophila, I. spruneri and I. simplex at different frequencies. Cortex of I. attica has thicker and more vascular bundles rays compared to I. spruneri. Endodermis can- 
Table 2. Characters used in cluster analysis.

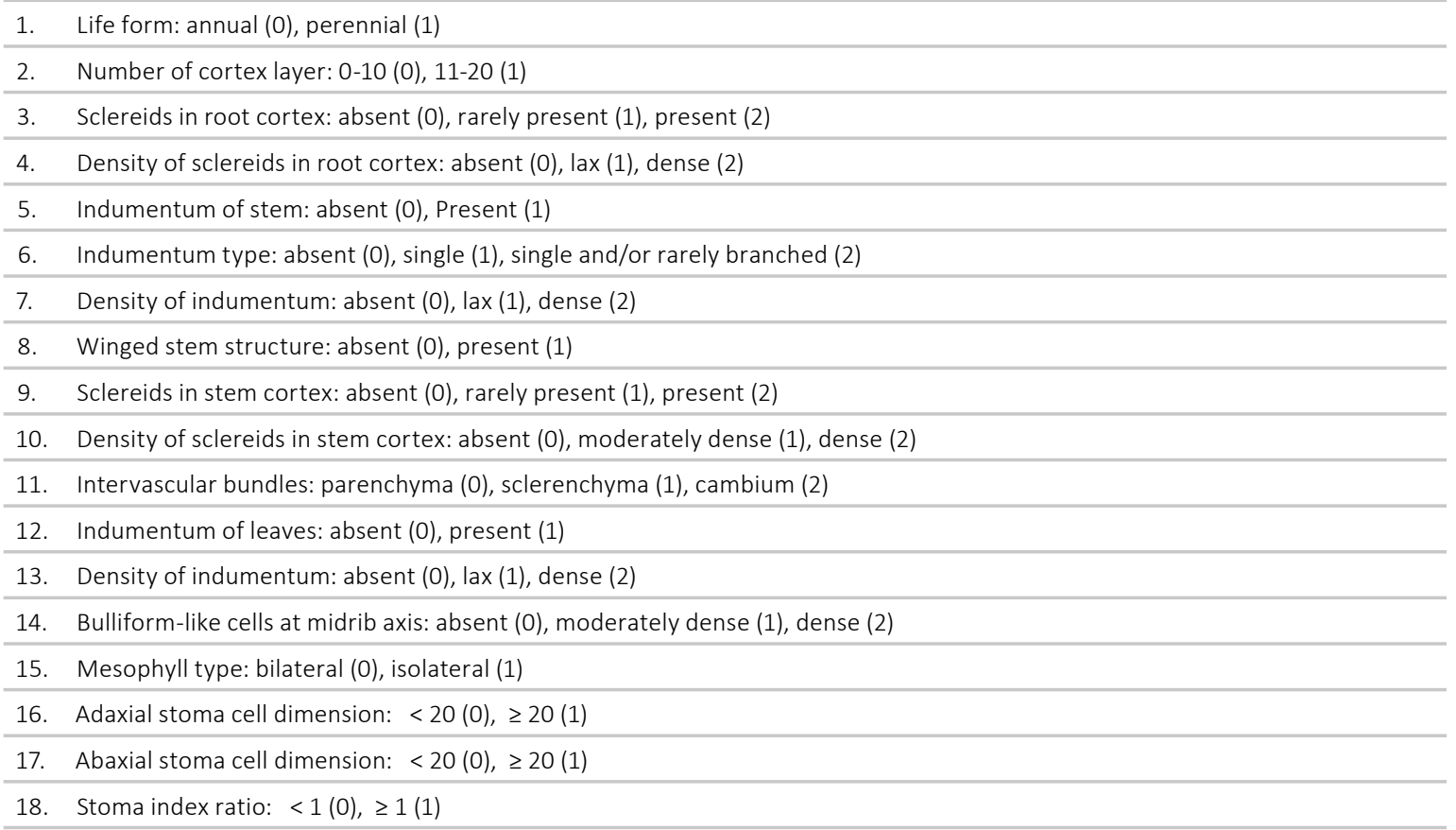

not be distinguished, and borders are not clear. Xylem is under phloem with secondary xylem and metaxylem regions, respectively (Figure 1 ). Measurements are listed in Table 3.

\section{Stem anatomy}

Single-layered epidermis is covered with a thin cuticula layer for all Iberis species (Figure 2). There are single cellular trichomes except for I. attica, which some branched trichomes are detected on the epidermis ( $\mathrm{Fi}$ gure $4 \mathrm{~b})$. I. attica is the only species that has a distinct winged stem structure (Figure 2a). Cortex is under epidermis, consisting of multi-layered parencymatic cells and all studied taxa have sclereids in the cortex of the stem at different frequency of cells (Figure 2). Phloem, vascular cambium and xylem are located between cortex and pith, respectively. In some species cambium is continuous, but in I. saxatilis, sclerenchyma cells (Figure

Table 3. Anatomical measurement of the root characters of studied taxa.

\begin{tabular}{ccccccccc}
\hline & I. attica & I. carica & I. halophila & I. odorata & I. saxatilis & I. sempervirens & I. simplex & I. spruneri \\
\hline $\begin{array}{c}\text { Annual (a) / } \\
\text { Perennial (p) }\end{array}$ & $\mathrm{p}$ & $\mathrm{p}$ & $\mathrm{p}$ & $\mathrm{a}$ & $\mathrm{p}$ & $\mathrm{p}$ & $\mathrm{p}$ & $\mathrm{p}$ \\
\hline Cortex layer & $8-11$ & $9-10$ & $10-15$ & $5-10$ & $10-16$ & $9-10$ & $15-20$ & $10-12$ \\
\hline $\begin{array}{c}\text { Sclereids in } \\
\text { cortex }\end{array}$ & $\begin{array}{c}\text { rarely } \\
\text { present }\end{array}$ & absent & present & absent & present & present & present & present \\
\hline $\begin{array}{c}\text { Density of } \\
\text { sclereids }\end{array}$ & $\begin{array}{c}\text { lax (if } \\
\text { present) }\end{array}$ & - & dense & - & lax & dense & lax & lax \\
\hline $\begin{array}{c}\text { Number of } \\
\text { rays }\end{array}$ & $4-10$ & $4-7$ & $5-7$ & $2-5$ & $4-5$ & $3-6$ & $4-5$ & $5-7$ \\
\hline
\end{tabular}



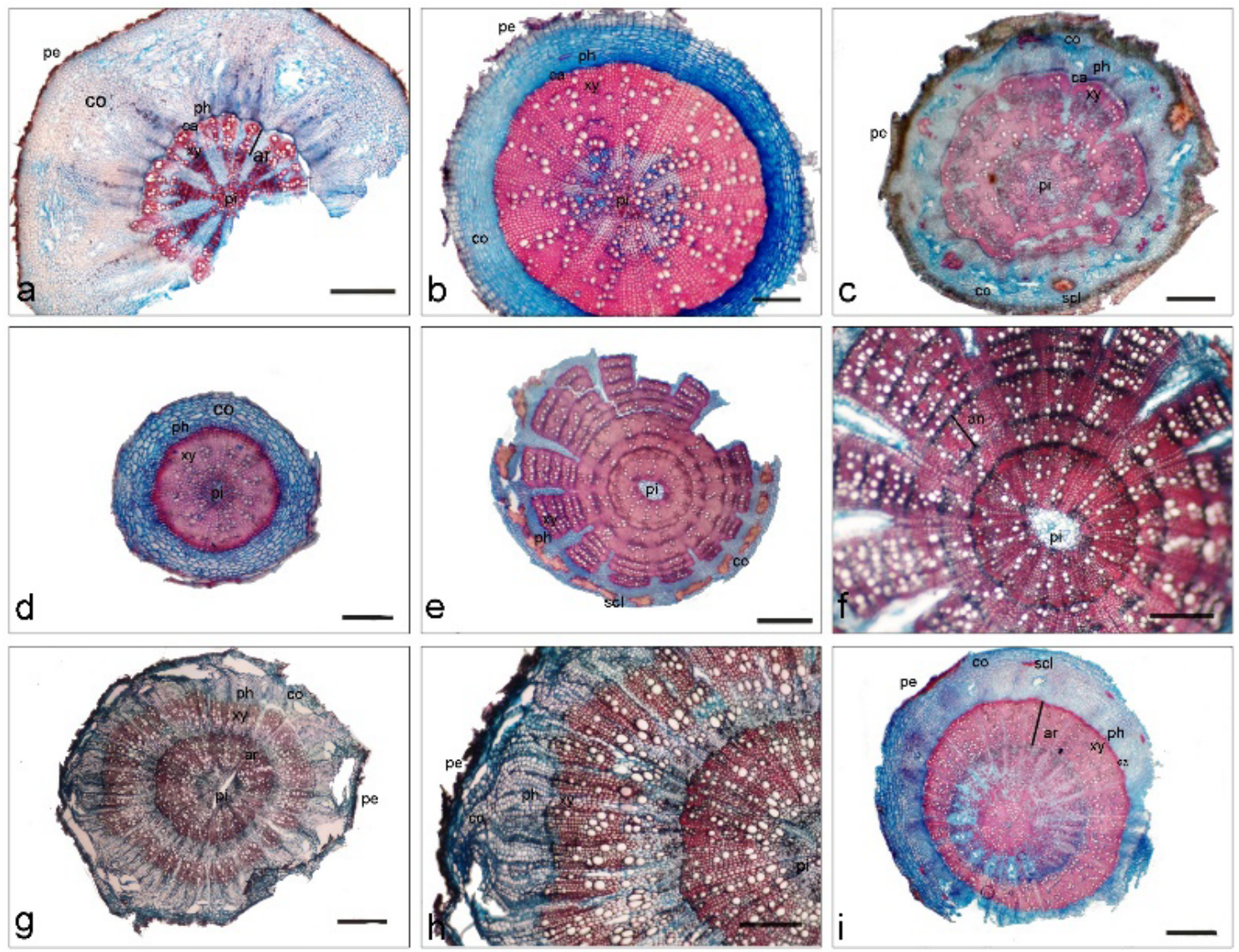

Figure 1. . Transverse sections of Iberis root.

a. I. attica (EÇ 1807), b. I. carica (EÇ 1829), c. I. halophila (EÇ 1766), d. I. odorata (HA 5877), e.-f. I. sempervirens (EÇ 1891), g.-h. I. simplex (EÇ 1887) and i. I. spruneri (HY 3794). ar, annual ring; ca, cambium; co, cortex; pr, periderm; ph, phloem; pi, pith region; sc, sclerenchyma; xy, xylem. Scale bars: (a, b, c, e, g, i) $500 \mu,(f, h) 200 \mu$.

$2 \mathrm{~h})$ and in I. odorata parenchyma cells (Figure 2j) are located between vascular tissues, and cambium activity cannot be seen in these parts. When mature, pith begins to scatter (Figure 2h, $m, n$ ). Some parenchymatic pith cells of the stem are differentiated as myrosin cells, where glucosinolate metabolism occurs and those myrosin cells resemble the sieve-tube cells of phloem in shape but not in function (Figure 2f, i, m). They appear as an ordinary parenchyma cells but include myrosinase enzyme [30]. Measurements are listed in Table 4.

\section{Leaf anatomy}

Iberis taxa found in Turkey generally have equifacial/ isolateral mesophyll structure, except I. attica and $I$. sempervirens; and are composed of multilayered palisade parenchyma cells. There is no sponge parenchyma, and stomatal cavities are small and narrow. This situation may be an adaptation to the arid habitat of these taxa. There is single-layered epidermis under cuticula and also has bulliform-like cells in some parts, especially at the midrib axis. The bulliform cells mainly found in grasses are capable of rolling up in dry or bad conditions and reopening again under favourable conditions [30]. It is thought that these bulliform-like cells in the genus Iberis may also be used for the reflection of the excessive day light (Figure 3). Measurements are listed in Table 5.

There are single and some branched trichomes on both adaxial and abaxial faces of leaves (Figure 4). Anticlinal cell walls are straight and the shape of the epidermal cells are irregular. The stomata of the genus are surrounded by three subsidiary cells of which one is usually much smaller than the other two, and it is a typical "cruciferous" (anisocytic) type stomata [15, 30-32]. As the shapes of the stomata are not different on both adaxial and abaxial sides of the leaves, we prefer to show the best figure for each taxon in Figure 5. In Table 6, all 

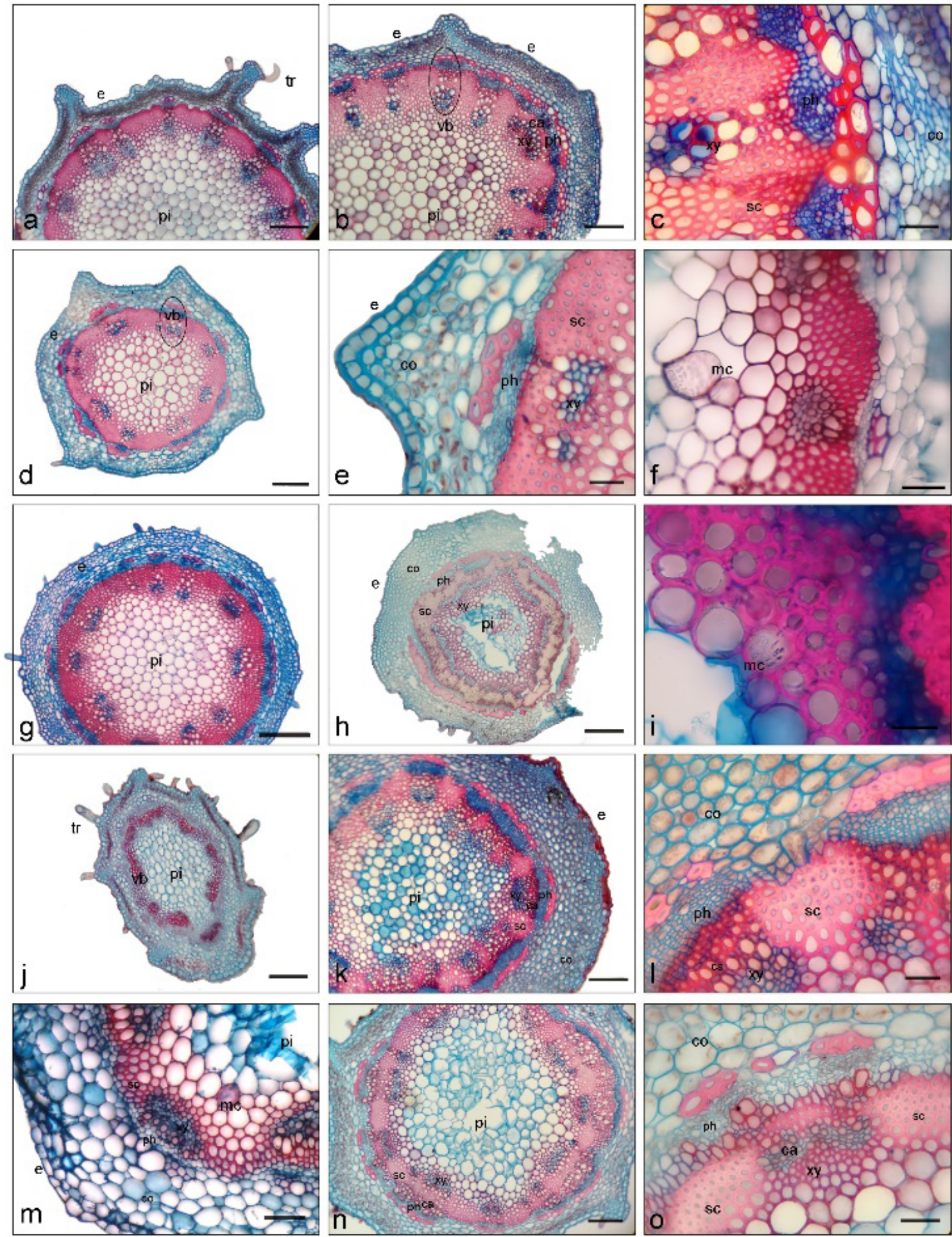

Figure 2. Transverse sections of Iberis stem.

a. I. attica (EÇ 1841), b-c. I. attica (EÇ 1889b), d, e and f. I. halophila (EÇ 1766), g. I. carica (EÇ 1829), h. I. saxatilis (TD 2516a), i. I. saxatilis - myrosin (DO 1376), j. I. odorata (HA 5877), k-I. I. sempervirens (EÇ 1891), m. I. spruneri (HY 3794), n-o. I. simplex (EÇ 1782). ca, cambium; co, cortex; ue, upper epidermis; le, lower epidermis; mc, myrosin cells; pa, palisade cell; sp, spongy parenchyma cell; ph, phloem; pi, pith region; sc, sclerenchyma; tr, trichome; xy, xylem. Scale bars: (d, h, j) $500 \mu,(a, b, g, k, n), 200 \mu$, (c, e, f, i, l, m, o) $50 \mu$. 
Table 4. Anatomical measurement of the stem characters of studied taxa.

\begin{tabular}{|c|c|c|c|c|c|c|c|c|}
\hline & 1. attica & 1. carica & 1. halophila & 1. odorata & $\begin{array}{c}\text { I. } \\
\text { saxatilis }\end{array}$ & $\begin{array}{l}\text { I. sempervi- } \\
\text { rens }\end{array}$ & 1. simplex & I. spruneri \\
\hline Indumentum & present & present & present & present & present & absent & present & present \\
\hline $\begin{array}{l}\text { Indumentum } \\
\text { type }\end{array}$ & $\begin{array}{l}\text { single and/ } \\
\text { or rarely } \\
\text { branched }\end{array}$ & single & single & single & single & - & single & single \\
\hline $\begin{array}{c}\text { Density of } \\
\text { indumentum }\end{array}$ & dense & dense & $\operatorname{lax}$ & $\operatorname{lax}$ & $\begin{array}{c}\text { lax; } \\
\text { (dense in ssp. } \\
\text { magnesiana) }\end{array}$ & - & dense & $\operatorname{lax}$ \\
\hline Winged structure & present & absent & absent & absent & absent & absent & absent & absent \\
\hline $\begin{array}{l}\text { Number of } \\
\text { cortex layer }\end{array}$ & $5-10$ & $8-15$ & $8-10$ & $6-8$ & $11-15$ & $10-13$ & $10-13$ & $6-13$ \\
\hline $\begin{array}{c}\text { Sclereids in } \\
\text { cortex }\end{array}$ & present & present & present & absent & present & absent & present & $\begin{array}{l}\text { rarely } \\
\text { present }\end{array}$ \\
\hline $\begin{array}{c}\text { Density of } \\
\text { sclereids }\end{array}$ & $\begin{array}{c}\text { moderately } \\
\text { dense }\end{array}$ & $\begin{array}{c}\text { moderately } \\
\text { dense }\end{array}$ & $\begin{array}{c}\text { moderately } \\
\text { dense }\end{array}$ & - & dense & - & $\begin{array}{c}\text { moderately } \\
\text { dense }\end{array}$ & $\begin{array}{c}\text { very lax (if } \\
\text { present) }\end{array}$ \\
\hline
\end{tabular}
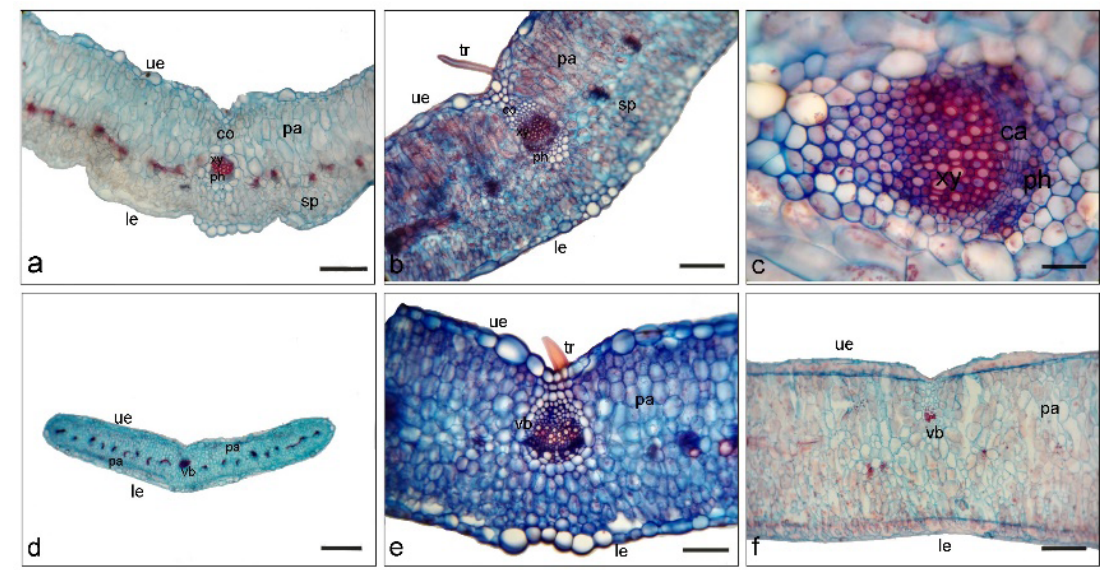

d
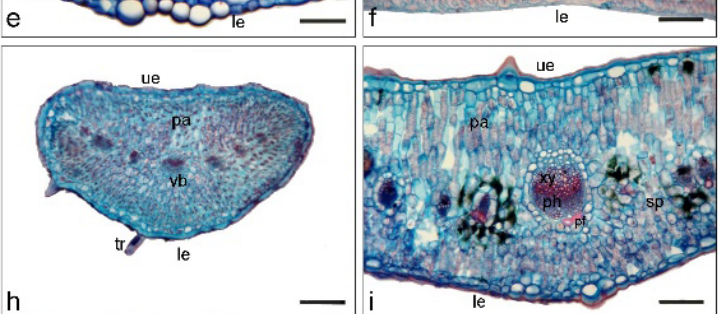

g
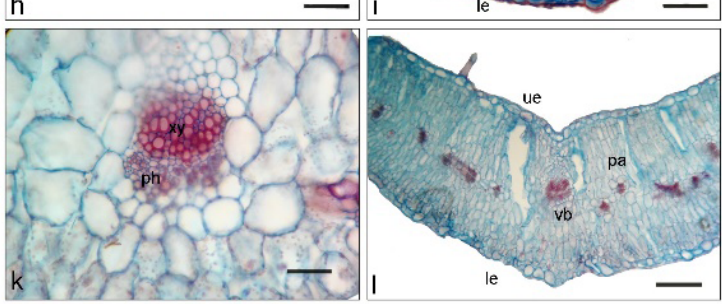

Figure 3. Transverse sections of Iberis leaves.

a. I. attica (EÇ 1891), b-c. I. attica (EÇ 1889b), d-e. I. carica (EÇ 1829), f. I. halophila (EÇ 1766), g. I. odorata (HA 5877), h. I. saxatilis (TD 2516a), i. I. sempervirens (EÇ 1891), j. I. simplex (EÇ 1782), k. I. simplex (EÇ 1887), I. I. spruneri (HY 3794). ca, cambium; co, cortex; ue, upper epidermis; le, lower epidermis; pa, palisade parenchyme cell; sp, spongy parenchyma cell; ph, phloem; pi, pith region; sc, scle-

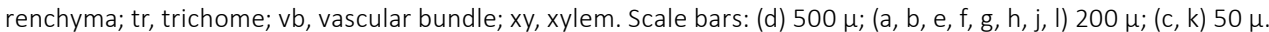


Table 5. Anatomical measurement of the leaf characters of studied taxa.

\begin{tabular}{ccccccccc}
\hline & I. attica & I. carica & I. halophila & I. odorata & I. saxatilis & $\begin{array}{c}\text { I. sempervi- } \\
\text { rens }\end{array}$ & I. simplex & I. spruneri \\
\hline Indumentum & present & present & present & present & present & absent & present & present \\
\hline $\begin{array}{c}\text { Density of } \\
\text { indumentum }\end{array}$ & dense & dense & lax & lax & $\begin{array}{c}\text { lax; (dense } \\
\text { in subsp. } \\
\text { magnesiana) }\end{array}$ & dense & dense \\
\hline $\begin{array}{c}\text { Bulliform-like } \\
\text { cells at midrib } \\
\text { axis }\end{array}$ & present & present & absent & absent & absent & $\begin{array}{c}\text { moderately } \\
\text { present }\end{array}$ & $\begin{array}{c}\text { moderately } \\
\text { present }\end{array}$ & $\begin{array}{c}\text { moderately } \\
\text { present }\end{array}$ \\
\hline
\end{tabular}

Table 6. Stomatal index of examined Iberis taxa.

\begin{tabular}{|c|c|c|c|c|c|c|c|}
\hline \multirow[t]{3}{*}{ Taxa } & \multicolumn{3}{|c|}{ Stoma cell } & \multicolumn{4}{|c|}{ Guard cell } \\
\hline & & & & Adaxial $(\mu)$ & & Abaxial $(\mu)$ & \\
\hline & Adaxial $\left(\mathrm{mm}^{2}\right)$ & Abaxial $\left(\mathrm{mm}^{2}\right)$ & $\begin{array}{c}\text { Stoma } \\
\text { index } \\
\text { ratio }\end{array}$ & Length & Width & Length & Width \\
\hline $\begin{array}{l}\text { 1. attica } \\
\text { (EÇ 1807) }\end{array}$ & $20.61 \pm 0.52$ & $18.35 \pm 0.75$ & 1,12 & $29 \pm 2.7$ & $23 \pm 1.3$ & $29 \pm 1.3$ & $23 \pm 2.2$ \\
\hline $\begin{array}{l}\text { I. attica } \\
\text { (EÇ 1849) }\end{array}$ & $21.11 \pm 2.82$ & $20.93 \pm 0.78$ & 1,01 & $28 \pm 3.4$ & $24 \pm 1.8$ & $31 \pm 1.6$ & $28 \pm 1.2$ \\
\hline $\begin{array}{l}\text { 1. attica } \\
\text { (EÇ 1889b) }\end{array}$ & $20.05 \pm 0.80$ & $23.46 \pm 0.42$ & 0,85 & $40 \pm 2.1$ & $31 \pm 1.7$ & $44 \pm 2.2$ & $31 \pm 1.7$ \\
\hline $\begin{array}{l}\text { I. attica } \\
\text { (EÇ 1841) }\end{array}$ & $23.49 \pm 1.33$ & $22.66 \pm 0.35$ & 1,04 & $33 \pm 2.0$ & $27 \pm 1.5$ & $28 \pm 2.7$ & $23 \pm 1.7$ \\
\hline $\begin{array}{l}\text { 1. attica } \\
\text { (EÇ 1759) }\end{array}$ & $20.13 \pm 0.69$ & $18.27 \pm 1.12$ & 1.10 & $46 \pm 3.3$ & $34 \pm 1.4$ & $40 \pm 1.9$ & $30 \pm 1.4$ \\
\hline $\begin{array}{l}\text { I. carica } \\
\text { (EÇ 1829) }\end{array}$ & $23.34 \pm 1.11$ & $23.58 \pm 1.75$ & 0,99 & $33 \pm 2.9$ & $29 \pm 3.0$ & $33 \pm 2.4$ & $26 \pm 1.6$ \\
\hline $\begin{array}{l}\text { 1. halophila } \\
\text { (EÇ 1766) }\end{array}$ & $22.48 \pm 0.96$ & $20.55 \pm 1.03$ & 1,09 & $35 \pm 2.8$ & $30 \pm 1.2$ & $32 \pm 2.2$ & $28 \pm 1.9$ \\
\hline $\begin{array}{l}\text { 1. odorata } \\
\text { (HY 5877) }\end{array}$ & $22.88 \pm 0.41$ & $23,95 \pm 1.59$ & 0,95 & $27 \pm 1.6$ & $24 \pm 1.7$ & $29 \pm 1.7$ & $25 \pm 1.7$ \\
\hline $\begin{array}{l}\text { 1. saxatilis } \\
\text { (TD 2516a) }\end{array}$ & $22.79 \pm 3.06$ & $21.80 \pm 1.99$ & 1,04 & $36 \pm 1.4$ & $31 \pm 2.6$ & $35 \pm 1.7$ & $30 \pm 2.2$ \\
\hline $\begin{array}{l}\text { I. sempervirens } \\
\text { (EÇ 1891) }\end{array}$ & $16.53 \pm 1.65$ & $21.17 \pm 0.99$ & 0,78 & $30 \pm 1.6$ & $25 \pm 1.0$ & $27 \pm 1.7$ & $25 \pm 0.9$ \\
\hline $\begin{array}{l}\text { I. simplex } \\
\text { (EÇ 1782) }\end{array}$ & $20.64 \pm 0.62$ & $23.30 \pm 1.46$ & 0,88 & $39 \pm 2.4$ & $30 \pm 3.0$ & $37 \pm 3.0$ & $29 \pm 1.4$ \\
\hline I. simplex (EÇ 1887) & $18.93 \pm 1.31$ & $20.80 \pm 1.53$ & 0,91 & $37 \pm 3.0$ & $28 \pm 1.2$ & $47 \pm 2.5$ & $34 \pm 1.8$ \\
\hline $\begin{array}{l}\text { I. spruneri (HY } \\
\text { 3794) }\end{array}$ & $18.50 \pm 0.35$ & $19.22 \pm 0.27$ & 0,96 & $33 \pm 1.3$ & $28 \pm 1.4$ & $29 \pm 1.2$ & $24 \pm 2.2$ \\
\hline
\end{tabular}



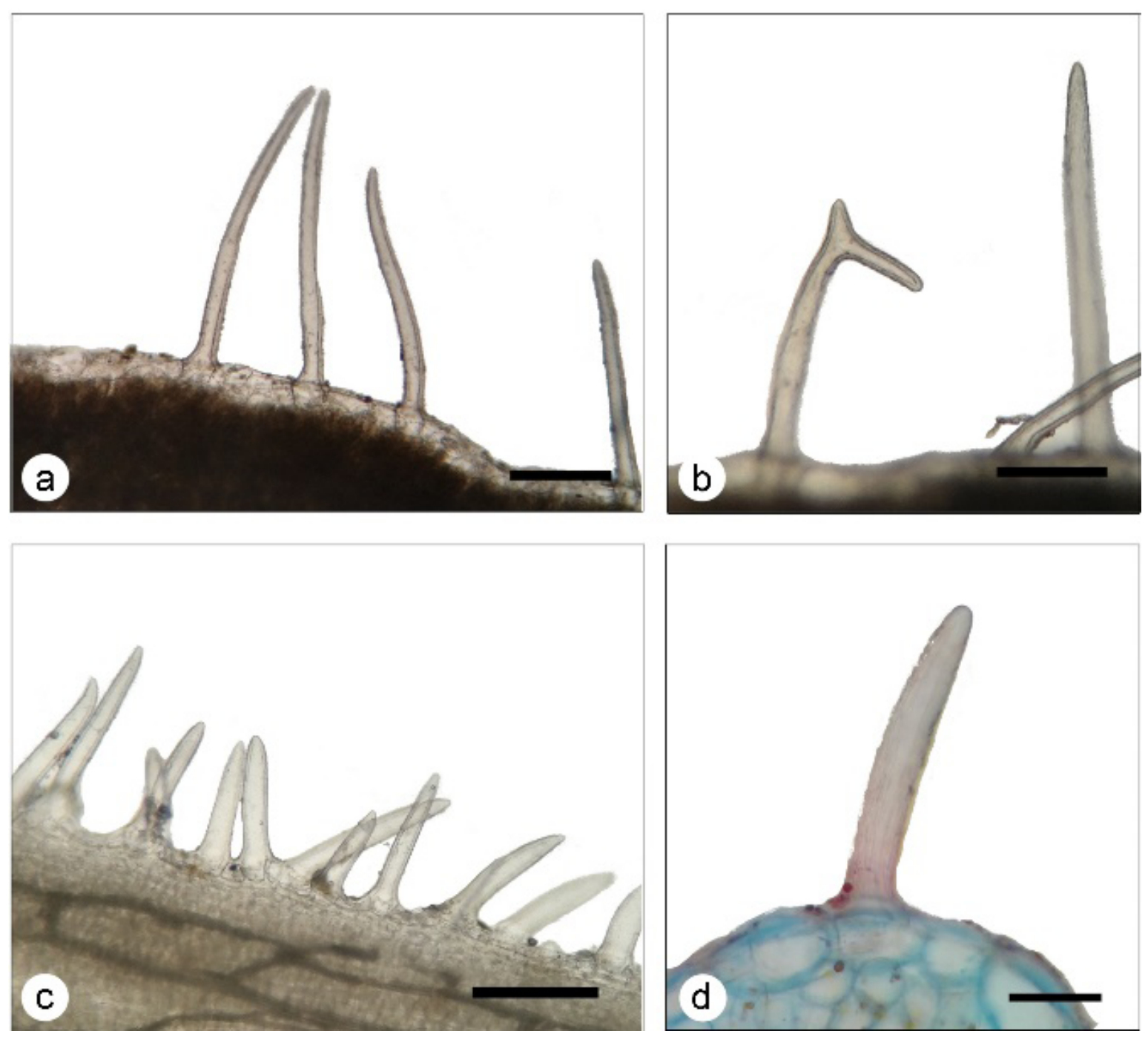

Figure 4. Trichomes.

a-b. I. attica (EÇ 1849); c, I. spruneri (HY 3794); d. I. attica (EÇ 1807). Scale bars: (a, b, c) $200 \mu$, (d) $50 \mu$.

measurements about the stomatal index of the taxa are indicated in detail. All studied taxa are amphistomatic and have stomata on both sides of the leaves (Figure 5).

\section{DISCUSSION}

The results of the current study suggest that anatomical features of Iberis taxa, which is natively found in Turkey help to improve the taxonomy of species and clarify the circumstance of the taxa.

The genus Iberis is evaluated anatomically for the first time in the present study. I. sempervirens is only species which subjected to the previous anatomical studies $[15$, 33]. Our results confirm that I. sempervirens is a peren- nial subshrub (Figure 1e, f) and the only species without indumentum. This may also be verified by its lowest stomatal index values (Table 6). This species could be easily diagnosed with its evergreen habit, glabrous stem and leaves, and white flowers (Figure 2k, I). I. sempervirens is one of the two taxa in which bifacial/dorsiventral leaf anatomy is seen. There are multilayered and frequently alined, quadrangular shaped palisade parenchyma cells in the adaxial side; and laxly alined with air spaces, roundly shaped sponge parenchyma cells at the abaxial side of the leaf (Figure 3i).

According to mesophyll structure in studied taxa, some leaves lack a distinction of layers, and others have wellseparated layers. While the mesophyll structure cannot 

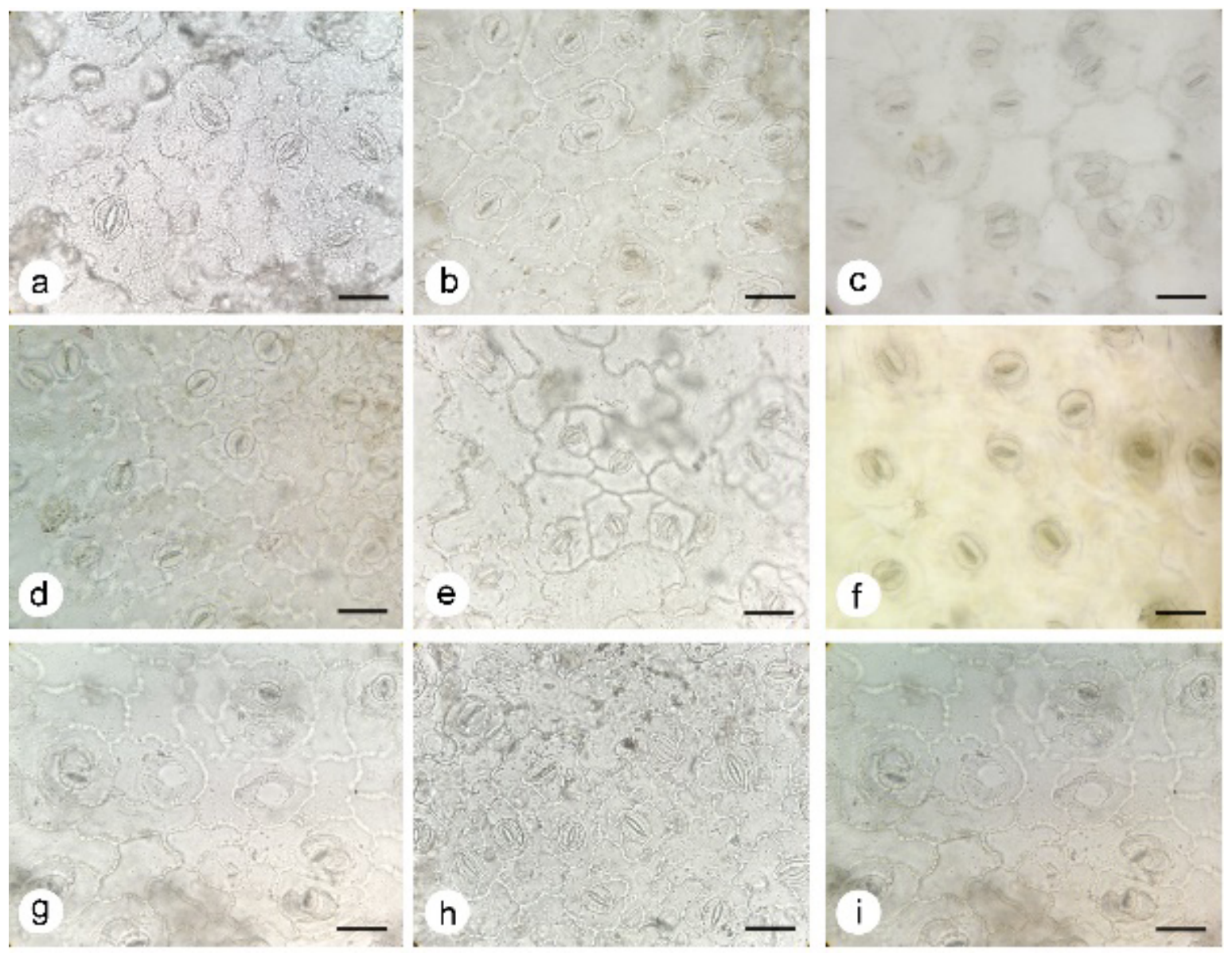

Figure 5. Stoma of Iberis taxa.

a. I. attica, le (EÇ 1759), b. I. attica, ue (EÇ 1807), c. I. carica, ue (EÇ 1829), d. I. halophila, ue (EÇ 1766), e. I. odorata, ue (HA 5877), f. I. saxatilis, ue (TD 2516a), g. I. sempervirens, ue (EÇ 1891), h. I. simplex, ue (EÇ 1887), i. I. spruneri, ue (HY 3794). Scale bars: $50 \mu$ (le: lower epidermis, ue: upper epidermis)

often be used as a diagnostic character to evaluate the taxonomic position of a plant, it may provide useful information about some allied group of taxa. Cutler's suggestion [30] that the mesophyll could be used as an aid to identification of these taxa, considering that environmental variations will not alter arrangements that are rigidly controlled by the genome, supports our findings. In the present study I. attica and. I. spruneri are taken into consideration separately instead of I. carnosa because of their anatomical differences, as well as their significant morphological and palynological distinctions (Çilden unpubl. data). I. attica is the only species of Turkish Iberis which has winged stem structure (Figure 2a, b), a valuable diagnostic character for stem anatomy (Table 4).

This species is distributed in the Mediterranean phytogeographic region from Izmir to Hatay including some parts of inner Anatolia, such as Karaman, Denizli, Burdur etc. and altitude from 30 to $1400 \mathrm{~m}$. This character could be an adaptation of stem to increase the surface area for photosynthesis. I. spruneri is morphologically small-sized species up to $10 \mathrm{~cm}$ and generally grows at high altitudes near subalpine (in Aydın, Denizli) and alpine zone (in Bursa-Uludağ). I. attica has bifacial/dorsiventral leaf anatomy (Figure 3a, b, c), whereas I. spruneri has isolateral (Figure $3 \mathrm{l}$ ). In addition, I. attica is the only species that has some branched trichomes on the epidermis besides unicellular simple hairs (Figure 4b). As a result, I. attica is considerably different from other Turkish Iberis taxa. Anatomical and palynological results from different I. attica populations shows that it is necessary to be examined in detail as a species complex. According to anatomical properties, I. attica and I. spruneri can be treated as two separate species. 


\section{Similarity between Iberis species}
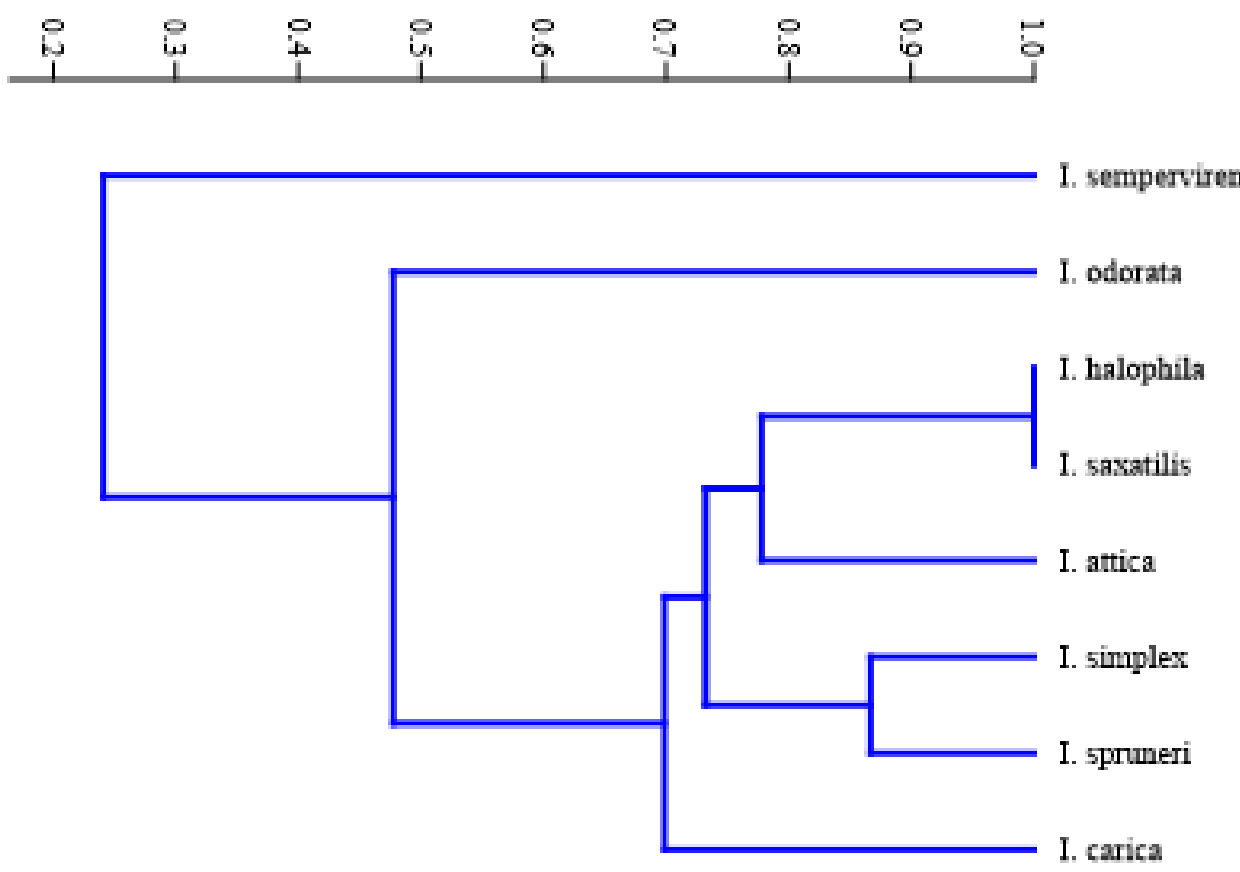

Figure 6. UPGMA phenogram about the relationship between Iberis species from Turkey.

I. carica is one of the three Turkish endemic taxa and unfortunately is the most misidentified Iberis species in Turkey. The common mistake made about the identification of I. carica is that the pre-admission of all Iberis species found in Aegean and/or Mediterranean regions of Turkey like İzmir, Aydın, Muğla and Antalya provinces as I. carica. But after the collection and examination of the type population (Aydın) in May 2018, we have found out that all other populations mentioned having been collected from Muğla, İzmir, Antalya and identified or doubtfully recorded as I. carica are I. attica. In addition to stomatal index values (Table 6), morphological and palynological results also verified the anatomical differences between 1 . carica collected from its type population and all I. attica populations, and with the other Iberis taxa (Çilden unpubl. data). In contrast with Flora of Turkey [5], I. carica has a perennial habit and isolateral leaf anatomy with locally placed bulliform-like epidermal cells. White flowers of this taxa are distinctly smaller than pinkish-purplish flowers of I. attica. Also, the cambium shows continuous structure between vascular bundles in I. carica and form an unbroken vascular circle in stem anatomy. However, I. attica, I. halophila, I. saxatilis, I. simplex and I. spruneri have sclerenchyma tissue between vascular bundles, whereas $I$. odorata and $I$. sempervirens have parenchyma. We have not been able to find any evidence if there is a transition between parenchyma and sclerenchyma cells or not, but noticed that this is a remarkable difference between Iberis taxa, especially for Turkish endemic I. carica.

I. halophila is one of the endemic species in Turkey and found only in Tuzgölü region, Aksaray province [9]. Since it is grown in salty habitat, the morphology of leaves turns to be succulent compared with other taxa. Leaves are mostly glabrous and rarely have lax indumentum in the upper leaves with isolateral structure. Also some parts of the root cortex seem to be scattered and this could be an adaptation to the salty habitat.

I. saxatilis has been known as a European Iberis species when it was found in Kazdağı, Balıkesir, and published as a new record for Turkey in 2005 [7]. In 2017, a new subspecies, I. saxatilis subsp. magnesiana Oskay was reported in Manisa province. Both taxa have a very restricted distribution area and I. saxatilis subsp. magnesiana is considered as endemic; found only in Soma. So, the distrubution area of these two taxa in Turkey are limited with Edremit (Balıkesir) and Soma (Manisa) districts for now, respectively. I. saxatilis subsp. magnesiana can 
be distinguished from I. saxatilis subsp. saxatilis by its retrorsely setulose stem and leave indumentum [13]. In the present study, we confirm the perennial habit and indumentum differences of these taxa. However, in $I$. saxatilis subsp. saxatilis, stem and leaves are not always glabrous and there is a sparsely distributed indumentum. The most important difference between I. saxatilis and the other Iberis taxa is the large amount of sclereids in the stem cortex of $I$. saxatilis, but the amount and density of sclereids are decreasing in root cortex. This could be the result of the calcerous and limestone structure of their habitats and of the semi-arid upper Meditteranean floristic region climate, they are found both in the upper part of the tree zone.

1. odorata is annual species and characterized with its 5-15 cm height of stem and the leaves with its short lobes [5]. Our results confirm its annual habit, and also we have found that there is no sclereids in the cortex of root and stem. There are parenchyma cells between the vascular bundles in stem, as seen also in I. sempervirens and the vascular cambium is not continuous. I. odorata has isolateral leaf anatomy as also seen in I. simplex, which has a broad distribution in Turkey. I. simplex is morphologically similar to I. attica with its whitishpurplish flowers, dense indumentum, but differs with its plant height, inflorescense, flower and fruit sizes and the distribution. As mentioned before, I. simplex has isolateral leaf anatomy whereas I. attica has bilateral. And in I. simplex there is no winged stem structure and branched trichomes can not be seen in the leaves.

Our cluster analysis based on anatomical characters is in partial agreement with Flora of Turkey [5] and indicates $I$. attica and I. spruneri have to be treated as separate species, in contrast with [12] and [28]. These contradictional results may come from different species conception of I. carnosa and/or mis-identification of some taxa (especially I. carica, I. attica, I. simplex and I. spruneri) (Figure 6).

As a conclusion, in this study we report a detailed study of anatomical properties of the genus /beris, which is native to Turkey, for the first time. Root, stem and leaf anatomies are investigated and stomatal index of taxa is determined. The anatomical parameters provide useful characters to improve the taxonomy of taxa in the genus Iberis. In addition, it is necessary to combine the anatomical results with palynological, karyological, macro and micromorphological and the molecular data as planned. Our results propose that I. attica and I. spruneri have to be considered as two separate taxa, not as synonyms of I. carnosa. And, endemic I. carica is perennial, not annual.

\section{Acknowledgments:}

We wish to thank Dr. Hasan Yıldırım, Dr. Ademi Fahri Pirhan, Dr. Barış Özüdoğru, Ilgın Deniz Can, Yusuf Emre Özdemir, Şeyda Çilden and Şinasi Çilden for their help in field works in Turkey between 2014 and 2019; and also to Dr. Dilek Oskay, Haşim Altınözlü, Ahmet Tıraş and Buse Topçuoğlu for collecting and sending someIberis specimens.

\section{References}

1. K. Marhold, Brassicaceae, in: Euro+Med Plantbase - the information resource for Euro-Mediterranean plant diversity. (2011). Available from: http://ww2.bgbm.org/EuroPlusMed/ PTaxonDetail.asp? NameCache $=$ Iberis \& PTRefFk $=7200000$ (accessed 19 June 2019)

2. I.A.Al-Shehbaz, Ageneric and tribal synopsis of the Brassicaceae (Cruciferae), Taxon 61 (2012) 931-954.

3. A. Busch, S. Horn, A. Mühlhausen, K. Mummenhoff, S. Zachgo, Corolla Monosymmetry: Evolution of a Morphological Novelty in the Brassicaceae Family, Molecular Biology and Evolution 29 (2011) 1241-1254.

4. S.K. Gupta, Biology and Breeding of Crucifers, CRC Press, 2009.

5. C. Hedge, Iberis L. In: Davis PH (editor). Flora of Turkey and the East Aegean Islands Vol. 1. Edinburgh: Edinburg University Press, pp. 309-312, 1965.

6. Ş. Yıldırımlı, Iberis L. In: Güner A, Özhatay N, Ekim T \& Başer KHC (editors), Flora of Turkey and the East Aegean Islands (Suppl.2), Vol 11, Edinburgh: Edinburgh University Press, pp. 31, 2000.

7. T. Dirmenci, F. Satıl, G. Tümer, A new record for the Flora of Turkey: Iberis saxatilis L. (Brassicaceae), Turkish J. Bot. 29 (2005) 471-474.

8. I.A. Al-Shehbaz, B. Mutlu, A.A. Dönmez, The Brassicaceae (Cruciferae) of Turkey, Updated. Turkish J. Bot. 31 (2007) 327336.

9. M. Vural, H. Duman, Z. Aytaç, N. Adıgüzel, A new genus and three new species from Central Anatolia, Turkey, Turkish J. Bot. 36 (2012) 427-433.

10. S. Yıldırımlı, The Chorology of the Turkish species of Brassicaceae family, Ot Sist. Bot. Der. 8 (2001) 141-169.

11. N. Özhatay, Check-list of Additional Taxa to the Supplement Flora of Turkey IV, Turkish J. Bot. 33 (2009) 197.

12. B. Mutlu, Iberis L. In: Güner A, Aslan S, Ekim T, Vural M, Babaç MT (editors), Türkiye Bitkileri Listesi (Damarlı Bitkiler), N. Gökyiğit Botanik Bahçesi \& Flora Araştırmaları Derneği Yayını, İstanbul, pp. 281-282, 2012.

13. D. Oskay, A new subspecies of Iberis saxatilis (Brassicaceae) from Turkey, Phytotaxa 306 (2017) 153-158.

14. B. Yılmaz Çıtak, M.B. Crespo, Correct citation and lectotype designation for the name Iberis carica (Brassicaceae), Phytotaxa 405 (2019) 297-300.

15. C.R. Metcalfe, L. Chalk Anatomy of The Dicotyledons, Leaves, Stem and Wood in Relation to Taxonomy with Notes on Economica Uses, Vol 1, London: Oxford, The Clarendon Press, pp. 79-87, 1957.

16. R.M.T. Dahlgren, A system of classification of the angiosperms to be used to demonstrate the distribution of characters. Botaniska Notiser 128 (1975) 119-147. 
17. M.F. Fay, M.J.M. Christenhusz, Brassicales-An order of plants characterised by shared chemistry, Curtis's Botanical Magazine, 27 (2010) 165-196.

18. APG III, An update of the Angiosperm Phylogeny Group classification for the orders and families of flowering plants: APG III, Botanical Journal of the Linnean Society 161 (2009) 105-121.

19. APG IV, An update o the Angiosperm Phylogeny Group classification for the orders and families of flowering plants: APG IV, Botanical Journal of the Linnean Society 181 (2016) $1-20$.

20. T.A.K. Prescott, G.C. Kite, E.A Porter, N.C. Veitch, Highly glycosylated flavonols with an O-linked branched pentasaccharide from Iberis saxatilis (Brassicaceae), Phytochemistry, 88 (2013) 85-91.

21. M.F. Mahomoodally, S. Vlaisavljevic, S. Berezni, H.H. Abdallah, G. Zengin, A.G. Atasanov, A. Mollica, D. Lobine, A. Aktümsek, Lotus aegaeus (Gris.) Boiss. and Iberis sempervirens L.: Chemical fingerprints, antioxidant potential, and inhibition activities and docking on key enzymes linked to global health problems, Indust. Crops \& Prod. 129 (2018) 271-278.

22. F. Tatsuzawa, Acylated pelargonidin glycosides from the red-purple flowers of Iberis umbellata $\mathrm{L}$. and the red flowers of Erysimum $\times$ cheiri (L.) Crantz (Brassicaceae), 2019. Phytochemistry, 159: 108-118.

23. J.K. Nielsen, L.M. Larsen, H. Sorensen, Cucurbitacin E and I in Iberis amara: feeding inhibitors for Phyllotreta nemorum. Phytochemistry, 16 (1977) 1519-1522.
24. T.F. Allen, The Encyclopedia of Pure Materia Medica vol. 5. Boericke \& Tafel, pp. 60-66, 1877.

25. I.A. Al-Shehbaz, M.A. Beilstein, E.A. Kellogg, Systematics and phylogeny of the Brassicaceae (Cruciferae): an overview, Plant Syst. Evol. 259 (2006) 89-120.

26. C.H. Huang, R. Sun, Y. Hu, L. Zeng, N. Zhang, L. cai, Q. Zhang, M.A. Koch, I.A. Shehbaz, P.P. Edger, J.C. Pires, D.-Y. Tan, Y. Zhong, H. Ma, Resolution of Brassicaceae phylogeny using nuclear genes uncovers nested radiations and supports convergent morphological evolution, Mol. Bio. Evol., 33 (2015) 394-412.

27. A. Busch, S. Zachgo, Control of corolla monosymmetry in the Brassicaceae, Iberis amara. Proceedings of the National Academy of Sciences, 104 (2007) 16714-16719.

28. B. Yılmaz Çıtak, A palynological survey of the genus Iberis (Brassicaceae), known as candytufts, in Turkey, Phytotaxa, 397 (2019) 213-224.

29. Ø. Hammer, D.A.T. Harper, P.D. Ryan, PAST: Paleontological statistics software package for education and data analysis, Palaeontologia Electronica, 4 (2001) 9.

30. K. Esau, Anatomy of Seed Plants. Second second edition, John Wiley and Sons, Inc., 1977.

31. D.F. Cutler, T. Botha, D.W. Stevenson, Plant Anatomy, An Applied Approach, Blackwell Publishing, 2007.

32. S. Yentür, Bitki Anatomisi, İstanbul: i. Ü. Fen Fakültesi, 2003.

33. F. Schweingruber, A. Börner, E.D. Schulze, Atlas of Stem Anatomy in Herbs, Shrubs and Trees 1 Springer-Verlag Berlin Heidelberg, 2001. 